\title{
Legislation and Policy
}

\author{
Faith T. Campbell, Hilda Diaz-Soltero, \\ and Deborah C. Hayes
}

\subsection{Introduction}

In the United States, biological invaders are managed by all Federal agencies that have responsibility for natural resources, as well as the States, territories, and occasionally regional entities. Federal agencies' invasive species programs are implemented under the mandates and guidance provided by dozens of laws, which include statutes enacted by the Congress, Executive Orders issued by the President, and regulations adopted by the relevant agencies. Although there are numerous laws implemented by the States or occasionally regional entities, this chapter will focus on Federal legislation and regulations that guide work on all public and private forests, rangelands, and grasslands in the United States. There are three categories of laws: (1) laws to prevent introduction or initial spread; (2) laws for management or control of invasive species; and (3) more generally defined land management laws which serve as an umbrella for invasive species activities.

Some of the most important Federal laws were enacted to prevent introduction and interstate spread of known or potential invaders. Some laws regulate modes of transport as well as the organisms themselves. Usually these powers do not reside in land- or water-managing agencies. Determination of the legal authority and responsible agency is based primarily on the anticipated impact of the nonnative invasive organism. Thus, the US Department of Agriculture (USDA) Animal and Plant Health Inspection Service (APHIS) is

F. T. Campbell ( $\bowtie)$

Center for Invasive Species Prevention, Springfield, VA, USA

H. Diaz-Soltero

U.S. Department of Agriculture, Animal and Plant Health

Inspection Service, San Juan, PR, USA

D. C. Hayes

U.S. Department of Agriculture, Forest Service, Sustainable Forest Management Research, Washington, DC, USA authorized to deal with a range of taxonomic groups considered to be "plant pests," as well as diseases of livestock and poultry. The Department of the Interior (DOI) US Fish and Wildlife Service (USFWS) regulates the introduction and spread of vertebrate animals and some invertebrates that the Secretary of the Interior has determined to be "injurious" to human beings; to the interests of agriculture, horticulture, forestry; or to wildlife or the wildlife resources of the United States. ${ }^{1}$

A small group of laws authorize Federal agencies to control invasive species where they have invaded. These laws often specifically direct either USDA or DOI as the lead for control or management; however, they apply to all Federal land management agencies. In addition to authorizing or mandating control of invasive species on Federal lands, there is often language that encourages cooperation between Federal agencies and States and private landowners. The law may even require an infrastructure for cooperation, such as appointing a coordinator within each program.

Other laws authorize and occasionally mandate more general programs implemented by land- and water-managing agencies. Most of these laws incorporate invasive species management into the agency's broader management goals for protecting wildlife (sometimes limited to specific taxa), habitats, natural resources, historic or cultural sites, etc. A few laws provide for the application of user fees to manage invasive species, or allow private entities operating under permit to be charged for the cost of managing invasive species.

This chapter will summarize the statutes which provide authority to regulate the introduction and spread of invasive species, including:

${ }^{1}$ Many of the older laws use older terms such as plant pests, noxious weeds, nuisance species, etc. rather than "invasive species." 
- The Plant Protection Act of 2000 [7 U.S.C. \$7701, et seq. (2000)]

- The "injurious wildlife" portions of the Lacey Act [18 U.S.C. $\S 42(a)(1)]$

- The Nonindigenous Aquatic Nuisance Prevention and Control Act (NANPCA) of 1990; as reauthorized by the National Invasive Species Act (NISA) of 1996 [P.L. 104332; 16 U.S.C. $§ 4701$, note]

Authorities specific to the USDA Forest Service will also be summarized or listed in this chapter.

In all cases, references will be provided to the full statute so that the specific legal authority may be analyzed in greater depth by those who are interested.

\subsection{Laws Regulating Introduction and Interstate Spread of Invasive and Potentially Invasive Species}

\subsubsection{Laws Regulating Movement of Invasive Plants and Plant Pests}

Regulatory authority over the introduction and spread of legally designated invasive plants (called "noxious weeds") as well as insects, nematodes, plant pathogens, and other invertebrates or micro-organisms that threaten native plants (called "plant pests") is exercised by USDA APHIS under the authority of the Federal Noxious Weed Act and the Plant Protection Act of 2000.

Federal Noxious Weed Act of 1974 The Federal Noxious Weed Act (FNWA) has been superseded by the Plant Protection Act of 2000 (7 U.S.C. § 7701, et seq.) except for the amendment adopted in 2004, Noxious Weed Control and Eradication Act of 2004 (P.L. 108-412), which remains in effect. $^{2}$ The amended statute provides, among other things, that USDA APHIS may prohibit or restrict the importation, entry, exportation, or movement in interstate commerce of any noxious weed, article, or means of conveyance, if the Secretary of Agriculture determines that the prohibition or restriction is necessary to prevent the introduction into the United States or the dissemination of the noxious weed within the United States. The term "noxious weed" is defined as any plant or plant product that can directly or indirectly injure or cause damage to crops (including nursery stock and plant products), livestock, poultry, or other interests of agriculture, irrigation, navigation, the natural resources of the United States, and the public. One hundred and twelve species are listed as Federal noxious weeds. The list is posted at https://plants.usda.gov/java/noxious or https://www.aphis.

\footnotetext{
${ }^{2}$ Numerous plant species considered to be invasive by various State agencies or other authorities are not listed under the FNWA, so they are not subject to its provisions.
}

usda.gov/plant_health/plant_pest_info/weeds/downloads/ weedlist.pdf. Citizens may petition the Secretary to add or delete species from the list.

Federal Seed Act of 1939 (7 U.S.C. $\$ 1551$, et seq.) The Federal Seed Act authorizes USDA APHIS to regulate interstate and foreign commerce in seeds and addresses "noxious weed seeds" that may be present in agriculture or vegetable seed.

Plant Protection Act (7 U.S.C. \$ 7701, et seq.) The Plant Protection Act (https://www.aphis.usda.gov/plant_health/ plant_pest_info/weeds/downloads/PPAText.pdf), adopted in June 2000, provides the legal foundation for USDA APHIS to regulate the importation, exportation, and interstate movement of plant pests, designated noxious weeds, biological control organisms, and plants or other articles which could transport these pests or weeds. Regulation of pests and invasive plants within individual States is carried out by that State except in cases when the Secretary of Agriculture declares an extraordinary emergency.

Organisms covered by the statute, in addition to noxious weeds (discussed above), are plant pests, defined as any living stage of any of the following that can directly or indirectly injure, cause damage to, or cause disease to any plant or plant product, including protozoans, nonhuman animals, parasitic plants, bacterium, fungus, virus, and infectious agents.

The Plant Protection Act prohibits importation or movement in interstate commerce (including by mail) of any plant pest unless otherwise authorized under the statute. The statute provides a petition process for adding or deleting organisms from the plant pest regulations. Policies and regulations must be based on sound science, transparent, and accessible.

The Secretary of Agriculture is authorized to prohibit or restrict the importation or movement in interstate commerce of any plant, plant product, biological control organism, noxious weed, article, or means of conveyance, if the Secretary determines that the prohibition or restriction is necessary to prevent the introduction into the United States or the dissemination of a plant pest or noxious weed within the United States.

The Secretary is also authorized to hold, seize, quarantine, treat, or apply other remedial measures to destroy or otherwise dispose of any plant, plant pest, noxious weed, biological control organism, plant product, article, or means of conveyance that-

1. is moving into or through the United States or interstate, or has moved into or through the United States or interstate, and-

(A) the Secretary has reason to believe is a plant pest or noxious weed or is infested with a plant pest or noxious weed at the time of the movement; or

(B) is or has been otherwise in violation of this title; 
2. has not been maintained in compliance with a post-entry quarantine requirement; or

3 . is the progeny of any plant, biological control organism, plant product, plant pest, or noxious weed that is moving into or through the United States or interstate, or has moved into the United States or interstate, in violation of this title.

The Secretary may order the owner of any plant, biological control organism, plant product, plant pest, noxious weed, article, or means of conveyance subject to action under subsection (a) of the Plant Protection Act, or the owner's agent, to treat or apply other remedial measures to destroy or otherwise dispose of the plant, biological control organism, plant product, plant pest, noxious weed, article, or means of conveyance, without cost to the Federal government.

USDA APHIS inspects imports of living plants-usually at one of its 16 Plant Inspection Stations. All other importsincluding fruits, vegetables, and grains for consumption and miscellaneous merchandise in packaging made from woodare inspected by the Bureau of Customs and Border Protection (CBP), a division of the Department of Homeland Security. The CBP inspections follow protocols and rules established by USDA APHIS.

Descriptions of USDA APHIS programs targeting major plant pests, including those that attack forest trees, are posted on the USDA APHIS website at https://www.aphis.usda.gov/ aphis/ourfocus/planthealth.

\subsubsection{Statutes Regulating Movement of Invasive Animals}

Regulatory authority over the introduction and spread of invasive or potentially invasive animals and their diseases is divided among several agencies, including the USFWS, Coast Guard, Environmental Protection Agency, US Army Corps of Engineers (Army COE), and US Department of Commerce National Oceanic and Atmospheric Administration (NOAA).

Lacey Act, Title 18 Available at https://www.fws.gov/le/ pdffiles/Lacey.pdf. The injurious wildlife provisions of the Lacey Act (18 U.S.C. $§ 42(a)(1))^{3}$ regulate importation and interstate movement of potentially harmful species belonging to certain specified taxa of wildlife. The Act was enacted in 1900 and has been subsequently amended. The Lacey Act is implemented by the USFWS.

The organisms covered by the Lacey Act include wild mammals, wild birds, fishes, reptiles, amphibians, mollusks,

${ }^{3}$ Other sections of the Lacey Act (16 U.S.C. $§ \S 3371-3378$ ) pertain to trafficking in protected species of wildlife and plants. and crustaceans. Some animals have been listed under the statute by law, including mongooses, fruit bats, brown tree snake (Boiga irregularis), zebra mussel (Dreissena polymorpha), and bighead carp (Hypophthalmichthys nobilis). Other species have been listed by regulation. As of May 2016, 611 species of wildlife are listed as injurious, including 301 fish, 201 amphibians, 92 mammals, 9 reptiles, 4 birds, 3 crabs, and 1 mollusk. Of the fish, 170 are salmonids that can serve as hosts of pathogens. All of the amphibians listed are salamanders that can serve as hosts of a pathogen.

The injurious wildlife provisions of the Lacey Act (18 U.S.C. $\$ 42(a)(1))$ state:

\begin{abstract}
The importation into the U.S., any territory of the U.S., the District of Columbia, the Commonwealth of Puerto Rico, or any possession of the U.S., or any shipment between the continental U.S., the District of Columbia, Hawaii, the Commonwealth of Puerto Rico, or any possession of the U.S., of [listed species] is hereby prohibited. All such prohibited mammals, birds, fish (including mollusks and crustacea), amphibians, and reptiles, and the eggs or offspring therefrom, shall be promptly exported or destroyed at the expense of the importer or consignee.
\end{abstract}

The USFWS' authority to regulate movements of listed species among the continental States has been reversed by the decision in United States Association of Reptile Keepers, Inc. v. Jewell, 103 F. Supp. 3d 133 (U.S.D.C., D.C. 2015). The decision by the District Court for the District of Columbia was upheld by the DC Circuit Court of Appeals.

Listing decisions are subject to the regulations at Title 50, Code of Federal Regulations (C.F.R.), Part 16. Species are added to the list of injurious wildlife to prevent their introduction, establishment, and spread in the United States, and to prevent harm they may cause to humans and the interests of agriculture, horticulture, forestry, or wildlife of the United States.

Since the statute does not allow for the listing of invertebrates other than mollusks and crustaceans, the pathogens and parasites that can be carried by wildlife cannot be listed by themselves. However, the USFWS has listed injurious wildlife because of their potential to introduce and spread harmful pathogens and parasites in the United States. Thus, USFWS has listed all members of the salmon family as injurious because of certain pathogens they may carry that can infect native and farmed salmonids. The USFWS also listed 201 species of salamanders because they might carry a fungus lethal to many salamander species.

Species are usually listed as injurious only as alive, but a listing may include dead individuals if the factor(s) that made the species injurious still exist(s) in a dead specimen. Gametes, viable eggs, and hybrids may also be included in a listing.

Possession of a listed species within State boundaries, and movement within the State, is the responsibility of each State and is not regulated by an injurious wildlife listing 
unless the organism has previously been permitted for importation or interstate transport. Similarly, export is not regulated by an injurious wildlife listing, provided the shipment is exported directly from a designated port without crossing State lines. Under the Lacey Act, USFWS may grant permits for the importation or interstate transportation of injurious wildlife or their offspring or eggs for zoological, educational, medical, or scientific purposes.

Nonindigenous Aquatic Nuisance Prevention and Control Act (NANPCA) of 1990; as reauthorized by the National Invasive Species Act (NISA) of 1996 P.L. 101646 (104 Stat. 4761), as amended by the National Invasive Species Act (NISA) of 1996 (P.L. 104-332; 110 Stat. 4073) The text of NISA is available at https://www.govinfo.gov/ content/pkg/PLAW-104publ332/html/PLAW-104publ332. htm.

The USFWS, US Coast Guard, Environmental Protection Agency, Army COE, and NOAA share responsibilities to develop a program of prevention, monitoring, control, and study to prevent introduction of and to control the spread of introduced aquatic nuisance species and the brown tree snake. The statutes also created the Aquatic Nuisance Species Task Force (ANSTF), which is co-chaired by the Undersecretary of Commerce for Oceans and Atmosphere and the USFWS Director. USDA is among the Task Force members. The Army COE is directed to establish an Aquatic Nuisance Species Research Program for developing control technologies to address aquatic invasive species (other than invasive aquatic plants). The Secretary of the Department of Homeland Security is required to ensure, to the maximum extent practicable, that aquatic nuisance species are not discharged into waters of the United States from vessels. Regulations require vessels to carry out management practices necessary to reduce the probability of unintentional discharges resulting from ship operations other than ballast water discharge (e.g., hull fouling). Jurisdiction under NISA (and NANPCA earlier) applies to the US territorial sea or within 12 nautical miles.

\subsubsection{Laws Regulating Species in Order to Prevent Introduction or Spread of Wildlife Diseases}

Animal Health Protection Act (P.L. 107-171, 7 U.S.C. § 8301, et. seq.) The Animal Health Protection Act (AHPA) authorizes USDA APHIS to prohibit the importation or entry of any animal or animal product that is likely to disseminate any foreign pest or disease of livestock (including farmed deer) or poultry within the United States. The AHPA prohibits the use of any means of conveyance in connection with the importation or entry of livestock if the means of conveyance has not been maintained in a clean and sanitary condi- tion. The Act also provides that USDA APHIS should maintain, in all regions of the United States, a sufficient number of Federal veterinarians and accredited State veterinarians who are well trained in recognition and diagnosis of exotic and endemic animal diseases. Under this statute, USDA APHIS has provided expertise to diagnose diseases in wild birds because the diseases could threaten domestic poultry.

Lacey Act, Title 18 The Lacey Act, Title 18, also regulates animals as a potential vector of disease. Refer to discussion above under Sect. 15.2.2.

\subsection{Laws Authorizing Federal Agencies to Control Invasive Species}

This section covers laws pertaining to specific Federal agencies to control invasive species.

Some of these laws go beyond just invasive species to give the agency a broad mandate within the original agency mission.

Animal Damage Control Act of 2000 (7 U.S.C. \$\$ 426426c, as amended) The Animal Damage Control Act gives USDA APHIS the authority to control wildlife damage on Federal, State, or private land. The purpose is to protect field crops, vegetables, fruits, nuts, horticultural crops, and commercial forests; freshwater aquaculture ponds and marine species cultivation areas; livestock on public and private range and in feedlots; public and private buildings and facilities; civilian and military aircraft; and public human health. In addition, USDA APHIS has broad authority for investigation, demonstrations, and control of mammalian predators, rodents, and birds. An amendment adopted in 1991 (P.L. 101-190 (Div. A, title III, Sec. 348, Dec. 5, 1991)) directs the Secretary of Agriculture to take actions to prevent introduction of brown tree snakes from Guam into other areas of the United States.

Federal Noxious Weed Act $\$ 15$ of the Federal Noxious Weed Act of 1974 (7 U.S.C. § 2801, note; 7 U.S.C. § 2814) Adopted in 1990, Section 15 titled "Management of Undesirable Plants on Federal Lands" authorizes the Secretary of Agriculture to cooperate with other Federal and State agencies and others in carrying out operations or measures to eradicate, suppress, control, prevent, or retard the spread of any noxious weed. Each Federal agency shall:

1. designate an office or person adequately trained to develop and coordinate an undesirable plants management program for control of undesirable plants on Federal lands under the agency's jurisdiction;

2. establish and adequately fund an undesirable plants management program through the agency's budgetary process; 
3. complete and implement cooperative agreements with State agencies regarding the management of undesirable plant species on Federal lands; and

4. establish integrated management systems to control or contain undesirable plant species targeted under cooperative agreements.

Public Law 109-59-Safe, Accountable, Flexible, Efficient Transportation Equity Act: A Legacy for Users or "SAFETEA-LU” 23 U.S. Code $\$ 145$ Text can be found at https://www.gpo.gov/fdsys/pkg/PLAW-109publ59/pdf/ PLAW-109publ59.pdf. For the first time, SAFETEA-LU provided eligibility for States to spend Federal-aid dollars on noxious weed programs. This is not mandatory spending; the choice is strictly up to the individual States.

Sec. 6006. Environmental Restoration and Pollution Abatement; control of noxious weeds and aquatic noxious weeds and establishment of native species.

(a) Modification to NHS/STP for Environmental Restoration, Pollution Abatement, Control of Noxious Weeds and Aquatic Noxious Weeds.-

1. Modifications to national highway system.-Section 103(b)(6) of title 23, United States Code, is amended by adding at the end the following:

"(Q) Environmental restoration and pollution abatement in accordance with section 328 .

(R) Control of noxious weeds and aquatic noxious weeds and establishment of native species in accordance with section 329."

2. Modifications to surface transportation program.Section 133 (b) of title 23, is amended by striking paragraph (14) and inserting the following:

“(14) Environmental restoration and pollution abatement in accordance with section 328 .

(15) Control of noxious weeds and aquatic noxious weeds and establishment of native species in accordance with section 329."

Part 329-Eligibility for control of noxious weeds and aquatic noxious weeds and establishment of native species.

“(b)Included Activities.-The establishment and management under subsection (a)(1) and (a)(2) may include-

1. right-of-way surveys to determine management requirements to control Federal or State noxious weeds as defined in the Plant Protection Act (7 U.S.C. 7701 et seq.) or State law, and brush or tree species, whether native or nonnative, that may be considered by State or local transportation authorities to be a threat with respect to the safety or maintenance of transportation systems;

2. establishment of plants, whether native or nonnative with a preference for native to the maximum extent possible, for the purposes defined in subsection (a)(1);

3. control or elimination of plants as defined in subsection (a)(2);

4. elimination of plants to create fuel breaks for the prevention and control of wildfires; and

5. training.".

\subsection{Laws Authorizing Invasive Species Management Programs as Part of Resource Management Agencies' Overall Programs}

\subsubsection{General Land Management Authorities}

These authorities deal with general land management and, for the most part, apply to all natural resource agencies. However, within the specific aim of the authorities, management of invasive species may be necessary to achieve the stated goals. This list of authorities is not exhaustive of all the general land management or other authorities which can be used.

Statutes pertinent to all resource management agencies

- Endangered Species Act (ESA) of 1973 (16 U.S.C. $\S \$ 1531$ et seq.)

- Surface Mining Control and Reclamation Act of 1977 (30 U.S.C. 1201, 1201 (note), 1236, 1272, 1305). §515

- North American Wetland Conservation Act 1989 (16 U.S.C. 4401 (note), 4401-4413, 16 U.S.C. 669b (note)). $\$ 9$ [U.S.C. 4408]

- National Historic Preservation Act of 1966 [16 U.S.C. $\S \S 470$ et seq.]

- Sikes Act (Fish and Wildlife Conservation) of September 15, 1960 (16 U.S.C. 670g-6701, 670o, P.L. 86-797), as amended. $\$ 201$

- Wilderness Act of 1964 (16 U.S.C. $\$ \$ 1131$ et seq.)

- Clean Water Act, section 404 (333 U.S.C. \$1344) on wetlands determination by Army COE and USFWS

\subsubsection{Statutes Authorizing Invasive Species Management Programs Implemented Specifically by the USDA Forest Service}

\subsubsection{Statutes Providing for Use of User Fees or Billing Permittees to Cover Costs of Managing Invasive Species}

Granger-Thye Act of April 24, 1950 (16 U.S.C. §§ 572) This statute authorizes the Secretary of Agriculture to cooperate with adjacent public and private landowners in performing work done for the "administration, protection, 
improvement, reforestation, and such other kinds of work the USDA Forest Service is authorized to do on lands of the United States." This law thus allows for cooperative abatement activities pertaining to invasive species on intermingled Federal and non-Federal land.

Cooperative Forestry Assistance Act (16 U.S.C. 2101, et seq.) This statute allows the USDA Forest Service to provide assistance to States for the management, protection, and development of nonindustrial private forest lands. Similarly, there is an urban and community forestry assistance program.

\subsubsection{Statutes Authorizing USDA Forest Service Management}

Included in this category are numerous statutes that broadly authorize invasive species management as a component of the agency's resource management activities in forests and grasslands of the United States:

- Organic Administration Act of 1897 (16 U.S.C. $\$ \$ 473$, et seq.). This law authorizes the Secretary to take such actions and regulate the occupancy and use of the National Forests to protect the forests thereon from "destruction by fire and depredations." 16 U.S.C. $\$ 551$.

- Forest and Rangeland Renewable Resources Research Act of 1978; especially §3(a)(3); 16 U.S.C. 1642. Section 3(a)(3) authorizes research for protecting renewable resources from "fires, insects, diseases, noxious plants, animals...."

- International Forestry Cooperation Act of 1990 (16 U.S.C. $\S 4501)$. Among many things, this statute authorizes the Secretary of Agriculture to provide international assistance for the "prevention and control of insects, diseases, and other damaging agents." 16 U.S.C. $\$ 4501$.

- Healthy Forests Restoration Act of 2003 (H.R. 1904) [16 U.S.C. 6501-6502, 6511-18, 6541-42, 6571-78]. The Restoration Act amended statutory processes for hazardous fuel reduction projects on certain types of at-risk National Forest System (NFS) and Bureau of Land Management (BLM) lands and provides other authorities and direction to help reduce hazardous fuel and restore healthy forest and rangeland conditions on lands of all ownerships. The act also establishes a program to combat infestations by forest-damaging insects and associated diseases (although the species prompting principal concern, the mountain pine beetle, is not an invasive species).

- Wyden Amendment (P.L. 109-54, Section 434). The Wyden amendment authorizes the Secretaries of Agriculture and Interior to enter into cooperative agreements to benefit resources within watersheds on certain lands under their respective jurisdictions. These agreements may support or conduct invasive species manage- ment activities on aquatic and terrestrial areas owned by local and State governments, tribes, other Federal agencies, private individuals, or organizations to benefit and protect public lands, the NFS, and other resources within a watershed at risk from invasive species.

\subsubsection{Regulations Governing USDA Forest Service Management of Invasive Species}

According to Section 2901.02 of the USDA Forest Service Manual, the Forest Service's authority to manage invasive species on NFS lands was delegated from the Secretary of Agriculture to the Under Secretary for Natural Resources and Environment at Title 7, C.F.R., Section 2.20 (7 C.F.R.§ 2.20). This authority has been delegated in turn from the Under Secretary to the Chief of the Forest Service at Title 7, C.F.R. Section 2.60 (7 C.F.R. § 2.60). Title 36, C.F.R. (including Parts 221, 222, 228, 241, 251, 261, 290, 292, 293, 296, and 297), provides additional authorities to manage and regulate invasive species across the NFS (national forests and national grasslands), including establishing requirements and prohibitions to prevent and control aquatic and terrestrial invasive species. Forest Service regulations at 36 C.F.R. $§ 222.8$ acknowledge the Agency's obligation to work cooperatively in identifying invasive species (including noxious weeds) problems and initiating control programs in aquatic and terrestrial areas of the NFS.

\subsubsection{Other Regulations and Policies Governing Specific Aspects of USDA Forest Service Invasive Species Management Programs}

Policy on Noxious Weed Management Departmental Regulation 9500-10 (DR 9500-10) (January 18, 1990) Established USDA policy to manage and coordinate noxious weed activities among USDA agencies in order to improve the quality and ecological conditions of crops and rangeland in the United States.

Policy on the Management of Wildlife, Fish, and Plant Habitat Departmental Regulation 9500-4 (DR 9500-4) Guides the management of Wildlife, Fish, and Plant Habitat on public lands.

Gypsy Moth Policy (USDA) of 1990 Departmental Regulation 5600-001 (DR 5600-001) This regulation established the Departmental Gypsy Moth Program. It assigns responsibilities to USDA agencies and defines agency roles to avoid duplication and provide maximum coordination of USDA activities dealing with gypsy moth.

Departmental Regulation 9500-4 (USDA policy on wildlife, fish, and plant habitat management on NFS lands and waters) This regulation provides that the Department will promote the concept and use of integrated 
pest management (IPM) practices in carrying out its responsibilities for pest control and will seek to alleviate damage by plant and animal pests to farm crops, livestock, poultry, forage, forest and urban trees, wildlife, and their habitats. Departmental agencies, through management and research programs, will develop or assist in developing new techniques and methodologies for the prevention of damage to agricultural or forestry production. The agencies also will strive to reduce potential depredations through improved management of USDA programs. Pest control techniques and considerations will be incorporated into appropriate management and education programs.

Native Plant Materials Policy (FSM 2070) of Feb 13, 2008 This policy provides USDA Forest Service manual direction on the use of native plant materials in revegetation, rehabilitation, and restoration of both aquatic and terrestrial ecosystems across the NFS.

Pesticide Use Management and Coordination Policy (FSM Chapter 2150) (March 19, 2013) This provides agency policy and guidance on the use of pesticides as part of an IPM approach. Additional guidance is provided in the Pesticide Use Management Handbook (FSH 2109).

In December 2011, the USDA Forest Service finalized a new title in the Forest Service Manual, FSM 2900-Invasive Species Management. The goal of the directive in FSM 2900 is to integrate invasive species prevention, early detection and rapid response, control, restoration, mitigation, cooperation, education, and awareness activities across forests and grasslands in the NFS resource management programs, Forest Plans, project-level planning activities, and other NFS operations.

The Manual states that all NFS invasive species management activities will be conducted within the following strategic objectives:

- Prevention Take proactive approaches to manage all aquatic and terrestrial areas of the NFS in a manner to protect native species and ecosystems from the introduction, establishment, and spread of invasive species.

- Early Detection and Rapid Response (EDRR) Inventory and survey susceptible aquatic and terrestrial areas of the NFS to quickly detect invasive species infestations, and subsequently implement immediate and specific actions to eradicate those infestations.

- Control and Management Conduct integrated invasive species management activities on priority aquatic and terrestrial areas of the NFS consistent with guidance from the National Invasive Species Council. (This statement includes the USDA guidance to use IPM.)

- Restoration Proactively manage aquatic and terrestrial areas of the NFS to increase the ability of those areas to be self-sustaining and resistant (resilience) to the establishment of invasive species.
- Organizational Collaboration Cooperate with other Federal agencies, State agencies, local governments, tribes, academic institutions, and private sector on invasive species issues.

The management of aquatic and terrestrial invasive species (including vertebrates, invertebrates, plants, and pathogens) will be based on an integrated pest management approach, throughout the NFS.

\subsubsection{Principal Statutes Governing Other Land-Managing Agencies}

Federal Lands Policy and Management Act of 1976 (FLPMA, 43 U.S.C. $\$ 1701$ et seq.) FLPMA directs the BLM to "take any action necessary to prevent unnecessary or undue degradation of the public lands," to "manage the public lands under principles of multiple use and sustained yield," and to include protection of "wildlife and fish."

Public Rangelands Improvement Act (43 U.S.C. \$ 1901 et seq.) This Act directs BLM to improve the range conditions of the public rangelands. BLM activities under the Act include reducing invasive species.

Taylor Grazing Act (43 U.S.C. § 315, et seq.) The Taylor Grazing act directs BLM to "make provision for the protection, administration, regulation, and improvement of [Federal] grazing districts" (43 U.S.C. $§ 315 a$ ); "to preserve the land and its resources from destruction or unnecessary injury" Id.; "to provide for the orderly use, improvement, and development of the range" Id.; and "to perform such work as may be necessary amply to protect and rehabilitate the areas subject to the provisions of this Act" Id. The Act also authorizes BLM to "cooperat[e] with ... official State agencies engaged in conservation or propagation of wildlife interested in the use of the grazing districts" Id. at $\S 315 \mathrm{~h}$.

National Park Service Organic Act (54 U.S.C. § 100,101, et seq.) The Organic Act established the National Park Service (NPS). It requires the agency to promote and regulate the areas known as national parks to conserve the scenery and the natural and historic objects and the wildlife therein and to provide for the enjoyment of the same in such manner and by such means as will leave them unimpaired for the enjoyment of future generations. This law generally gives the NPS the authority to regulate the movement of invasive species. Section 15.3 expressly authorizes the destruction of detrimental animals, which includes invasive species.

National Wildlife Refuge Administration Act (16 U.S.C. \$\$668dd-ee) This Act establishes the National Wildlife Refuge (NWR) System and requires USFWS to administer lands to provide for the conservation of fish, wildlife, plants, and their habitats and to ensure that biological integrity and diversity are maintained. Under implementing 
regulations promulgated at 50 C.F.R. $\S 27.52$, USFWS prohibits introduction of plants and animals taken elsewhere to any NWR except as authorized.

\subsection{Executive Orders}

Executive Order 13112 Executive Order (EO) 13112 (available at https://www.invasivespeciesinfo.gov/executive-orders-invasive-species) directs Federal agencies to (1) identify actions that may affect status of an invasive species; (2a) prevent introduction of such species; (2b) detect and control such species; (2c) monitor population of such species; (2d) provide for restoration of native species; (2e) conduct research on invasive species and develop technologies to prevent introduction of such species; (2f) promote public education of such species; and (3) not authorize, fund, or carry out actions likely to cause the introduction or spread of invasive species in the United States or elsewhere, unless the benefits of the action clearly outweigh the harm and the agencies take steps to minimize the harm.

Executive Order 13112 defines invasive species as "an alien species whose introduction does or is likely to cause economic or environmental harm or harm to human health." To understand the full meaning of the term "invasive species" within the EO, the definition of "Introduction" needs to be inserted. "Introduction" means the intentional or unintentional escape, release, dissemination, or placement of a species into an ecosystem as a result of human activity. Thus, the actual working definition to use for invasive species is "an alien species whose introduction (the intentional or unin- tentional escape, release, dissemination, or placement of a species into an ecosystem as a result of human activity) does or is likely to cause economic or environmental harm or harm to human health." The definition of what is meant by harm is further elaborated in a white paper issued by the Invasive Species Advisory Council. The paper is available at https://www.doi.gov/sites/doi.opengov.ibmcloud.com/files/ uploads/ISAC $\% 20$ Definititions $\% 20$ White $\% 20$ Paper $\% 20$ $\% 20-\% 20$ FINAL $\% 20$ VERSION.pdf.

Executive Order 13112 also establishes the National Invasive Species Council (NISC). NISC is co-chaired by the Secretaries of Agriculture, Commerce, and the Interior. Its membership encompasses 13 member departments and their constituent agencies. The Council's work is supported by a small staff. NISC responsibilities include promoting action at local, State, tribal, and ecosystem levels; identifying recommendations for international cooperation; facilitating a coordinated network to document, evaluate, and monitor invasive species' effects; developing a web-based information network on invasive species; and developing guidance on invasive species for Federal agencies to use in implementing the National Environmental Policy Act.

Executive Order 13112 also established the Invasive Species Advisory Council. Members are appointed by the Secretary of Interior; the Council operates under transparency and other provisions of the Federal Advisory Committee Act (FACA) (Pub. L. 92-463, § 1, Oct. 6, 1972, 86 Stat. 770).

Disclaimer Text The findings and conclusions in this publication are those of the authors and should not be construed to represent any official USDA or U.S. Government determination or policy.

Open Access This chapter is licensed under the terms of the Creative Commons Attribution 4.0 International License (http://creativecommons. org/licenses/by/4.0/), which permits use, sharing, adaptation, distribution and reproduction in any medium or format, as long as you give appropriate credit to the original author(s) and the source, provide a link to the Creative Commons license and indicate if changes were made.

The images or other third party material in this chapter are included in the chapter's Creative Commons license, unless indicated otherwise in a credit line to the material. If material is not included in the chapter's Creative Commons license and your intended use is not permitted by statutory regulation or exceeds the permitted use, you will need to obtain permission directly from the copyright holder. 